\title{
Primary oral mucosa-associated lymphoid tissue (MALT) lymphoma in patient with monoclonale gammopathy: a rare case report
}

\author{
Hilal Hafian ${ }^{1,2,3,8^{*}} \mathbb{0}$, Hubert Schvartz ${ }^{4,5}$, Martine Patey ${ }^{4,5}$ and Anne Quinquenel ${ }^{6,7}$
}

\begin{abstract}
Background: Monoclonal gammopathy is a biological reality encountered in approximately $1 \%$ of the general population. In the absence of clinical and biological signs, it is considered of undetermined significance; however, it can be a biological signature of a monoclonal lymphocytic or plasma-cell proliferation. Their localisation to the oral mucosa remains rare and difficult to diagnose, particularly in indolent forms that escape imaging techniques.

Case presentation: Here, we report the case of a 73-year-old woman with a history of IgM kappa gammopathy followed for 13 years. The patient did not have a chronic infection or an autoimmune disease, and all the biological investigations and radiological explorations were unremarkable during this period. The discovery of a submucosal nodule in the cheek led to the diagnosis of MALT lymphoma and regression of half of the IgM kappa level after resection. The review of the literature shows the dominance of clinical signs (i.e., a mass or swelling) in the diagnosis of primary MALT lymphomas of the oral cavity after surgical resection.
\end{abstract}

Conclusions: Our case illustrates the role of examination of the oral cavity in the context of a monoclonal gammopathy. The absence of clinical and radiological evidence in favor of lymphoplasmacytic proliferation, does not exclude a primary indolent MALT lymphoma of the oral mucosa.

Keywords: Mucosa-associated lymphoid tissue (MALT), Monoclonal gammopathy, Lymphoma, Oral mucosa, Light chain, Haemopathy, Head and neck, Extra nodal

\section{Background}

Monoclonal gammopathy of undetermined significance (MGUS) is defined as serum-M protein lower than $30 \mathrm{~g} / \mathrm{L}$, fewer than $10 \%$ clonal plasma cells (PCs) in the bone marrow (BM) and, most importantly, the absence of organ damage that can be attributed to PC proliferative disorder [1]. It is an asymptomatic

\footnotetext{
*Correspondence: hilal.hafian@gmail.com

${ }^{8}$ Département de Médecine et Chirurgie Orales, Pôle de Médecine

Bucco-Dentaire, Centre Hospitalier Universitaire de Reims, 45, Rue

Cognacq-Jay, 51100 Reims, France

Full list of author information is available at the end of the article
}

condition characterised by the absence of any isolated monoclonal lymphocytic and/or plasmocytic proliferative component forming a tumour and the absence of any other biological abnormality. This is the case for more than $60 \%$ of monoclonal gammopathies [2]. MGUS is present in $1-3 \%$ of the general population over 50 years of age and up to $5 \%$ of those over 70 years of age [3]. They are mostly fortuitous discoveries made in the course of a systematic medical check-up motived by various symptoms or biological abnormalities, which are at first glance unrelated to a malignant haematolymphoid disorder. However, monoclonal 
gammopathy can also be discovered due to a complication related to the monoclonal component, primarily autoimmune, such as cytopenia, coagulopathy, autoimmunity or cryoglobulin activity. The renal complications associated with MGUS have been identified as a new entity called monoclonal gammopathy of renal significance (MGRS) [4]. The main complications of MGUS are the risk of progression to malignant haemopathy, such as multiple myeloma (MM) (isotype IgG, IgA and light chains without heavy chains) or B-cell lymphoproliferative haemopathy (mainly IgM isotype) [5]. The risk of progression is approximately $1 \%$ per year [6]. but almost $90 \%$ of MGUS cases will never develop lymphoproliferative malignancies. This is why the current clinical recommendation is longterm clinical monitoring for the majority of patients with MGUS [1]. A monoclonal gammopathy, however, can be a blood biological signature of secretory PCs in lymphoplasmacytic disorders, as in MM, extramedullary or solitary plasmacytoma, primary amyloidosis and Waldenström macroglobulinaemia, but also in approximately one-third of mucosa-associated lymphoid tissue (MALT) lymphomas [7] or other B-lymphoproliferative disorders. MALT lymphomas, which are subtypes of non-Hodgkin lymphomas, are B-cell lymphomas of the extranodal marginal zone B cells $[8,9]$. They constitute approximately $11 \%$ of B-cell lymphomas associated with lymphoid tissues of the mucosa [10]. Most cases occur in adults, in the sixth and seventh decades, with slight predominance for females [9]. These lesions are characterised by their tendency to remain localised and are often set in an inflammatory background due to infection or autoimmunity. The most common site for these lymphomas in the gastrointestinal tract is the stomach, where they are mostly related to a Helicobacter pylori infection; however, MALT lymphomas can occur in other common sites, including salivary glands, lung, head and neck mucosa, ocular adnexa, skin, thyroid and breast [11-13]. The risk of development of MALT lymphoma is increased in patients with autoimmune diseases such as Sjögren's syndrome, Hashimoto's thyroiditis or lymphoepithelial sialadenitis.

MALT lymphomas may also occur in the oral cavity; this location is extremely rare and is most frequently discovered by clinical manifestations such as swelling or a submucosal mass $[10,14]$. We report the case of primary indolent MALT lymphoma localised in the cheek, discovered as an infra-centimetric submucosal mass in a 73-year-old woman who had been followed for more than 13 years for an IgM kappa MGUS that decreased after surgical excision of the nodule of the cheek.

\section{Case presentation}

A 73-year-old female was referred by a dentist for the extraction of the residual root of the second right mandibular premolar (Fig. 1). She was followed for 13 years for an IgM kappa monoclonal gammopathy with a serum level at $13.16 \mathrm{~g} / \mathrm{L}$ at the time of consultation. The patient had no autoimmune disease history. Medical imaging during the 13-year follow-up of the gammopathy did not identify any lesions or suspicious images. All computed tomography (CT) and magnetic resonance imaging (MRI) of the pelvis, abdomen, chest and head and neck were without abnormality. A total body positron emission tomography/computed tomography (PET/CT) was performed routinely, since the diagnosis of monoclonal gammopathy did not show suspect hypermetabolic focus. Biological analysis of the patient's blood count was without abnormality, C-reactive protein level increased gradually over the 13 years of follow-up, and all sternal BM aspirations performed were also without abnormality.

The intraoral visual examination did not show any mucosal lesions; however, salivation was normal and the patient had no symptoms, especially pain or swelling. A thorough systematic physical examination was performed, with free bidigital palpation of the floor of the mouth and left cheek, but palpation of the right cheek revealed a submucosal infra-centimetric and irregular nodular lesion underneath the orifice of the Stenon canal (Fig. 2). It was not fixed to the deep plane and was of firm consistency. No cervical lymphadenopathy was found. In the context of monoclonal gammopathy, surgical excision of this nodule was performed under local anaesthesia, at the same operating time as the extraction of the residual root of the second right mandibular premolar. The excised tissue consisted of a brownish yellow tissue measuring $0.8 \mathrm{~cm} \times 0.7 \mathrm{~cm} \times 0.5 \mathrm{~cm}$. On pathological examination, the lesion was firm and the cut surface yellowish-white. Microscopically, dense lymphomatous proliferation of the pseudo-nodular architecture was present,

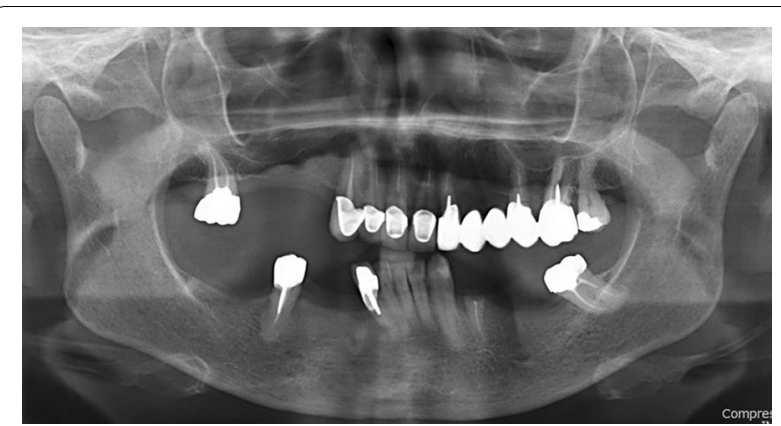

Fig. 1 Panoramic radiography at the first consultation negative for pathological bone imaging 


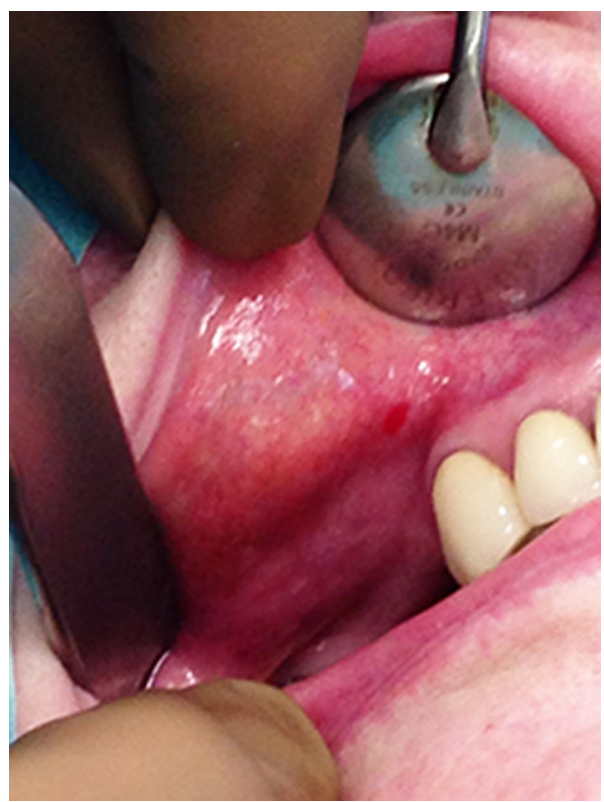

Fig. 2 Intraoral view of submucosal nodule of the right check

revealing some germinal centres colonised by a lymphomatous infiltrate, which also widened the marginal zone and infiltrated the interfollicular areas (Fig. 3a). Proliferation of the tumour tended to massively infiltrate the germinal centres with invasion of the adipose tissue and insheathing of the nerve filaments (Fig. 3b). The diffuse proliferation of tumour cells in the marginal zone was formed of cells of small size, with irregular nuclei, but that were rarely nucleated. The tumour cells had rather dense chromatin nuclei with a cytoplasm that was sometimes off-centred and a plasma-cell differentiation (Fig. 3c), We found some mast cells. There were no Dütcher body-type intra-nuclear inclusions. Immunohistochemical study of the lymphomatous proliferation showed that the tumour cells expressed CD20 and CD79a (Fig. 3d, e), monoclonal heavy chain IgM (Fig. 3f), and kappa light chain (Fig. 3g) and were negative for lambda light chain (Fig. $3 \mathrm{~h}$ ).

Many tumour cells expressed CD5- and anti-CD3staining marked T-lymphocytes. A network of cells was immunolabelled for CD10, BCL2, BCL6, MUM1 and cyclin D1. The BCL2 and MUM1 markers were expressed by many PCs. CD21 and CD23 highlighted the dendritic cells in residual dislocated germinal centres. Histological examination did not show lymphoepithelial structure, and the anti-AE1/AE3 immunolabelling was negative. The final diagnosis was primary MALT lymphoma.

The patient was referred to the Haematology department, and no indication of specific treatment was retained in the absence of symptoms or high tumour burden. With a follow-up of 4 years, no local recurrence or dissemination was observed clinically or in annual CT scans. Biological assessment, particularly thyroid, hepatic and renal, remained normal, and electrophoresis of the plasma proteins showed a decrease in the serum level of IgM kappa to $7 \mathrm{~g} / \mathrm{L}$, probably favoured by the surgical excision of the primary isolated MALT lymphoma of the mucosa of the cheek.

\section{Discussion}

MGUS is present in roughly 3-4\% of the population over 50 years of age and in approximately $5 \%$ of those older than 70 years [3] and virtually precedes the development of MM and related disorders, i.e., lympho-plasma-cellular neoplasms, Waldenström macroglobulinaemia, lightchain amyloidosis and also non-Hodgkin's lymphoma (NHL) [15]. It has been defined by the International Myeloma Working Group (IMWG) as a plasma-cell disorder characterised by a serum monoclonal level lower than $30 \mathrm{~g} / \mathrm{L}, \mathrm{BM}$ PCs lower than $10 \%$ and absence of organ damage, lytic bone lesions, hypercalcaemia or renal failure, and which can be attributed to a plasma-cell proliferative disorder $[1,16,17]$. The IgM MGUS is a MGUS subtype that presents a risk of progression to NHL, and especially Waldenström macroglobulinaemia [18], whereas non-IgM MGUS (i.e., IgA, IgG or, rarely, IgD or IgE) are assumed to be associated with the risk of plasmacell tumour development, although definitive diagnosis should include BM examination [19, 20], Prediction of the risk progression of MGUS patients who will remain stable compared to those who progress is very difficult at the time of recognition of the MGUS; however, the level and type of $\mathrm{M}$ protein, the number of BM PCs (if a BM aspiration is performed) and the free light-chain ratio, can be used to stratify the risk of progression of MGUS to $\mathrm{MM}$ or related disorders [21] and enable monitoring and patient management as dictated by the IMWG guidelines [22].

Non-Hodgkin's lymphomas of the oral cavity are rare tumours. They represent $10-15 \%$ of extranodal lymphomas and less than $5 \%$ of malignant tumours of the oral cavity. This is the third most common tumour group after squamous cell carcinoma and malignant tumours of the salivary glands $[23,24]$. B-cell lymphoma is the most common histological form, and over $70 \%$ of cases are of diffuse large B-cell (DLBCL)-subtype lymphomas with preferential localisation to the oropharynx, followed by follicular lymphoma (11.1\%), and extranodal marginal zone MALT lymphoma (9.2\%) [10].

MALT lymphoma is considered an extranodal variant of marginal zone B-cell lymphoma and is a distinct entity of NHL [9]. It is more frequent in women older than 60 years of age, but some cases have been reported in children, as shown by the literature data summarised 

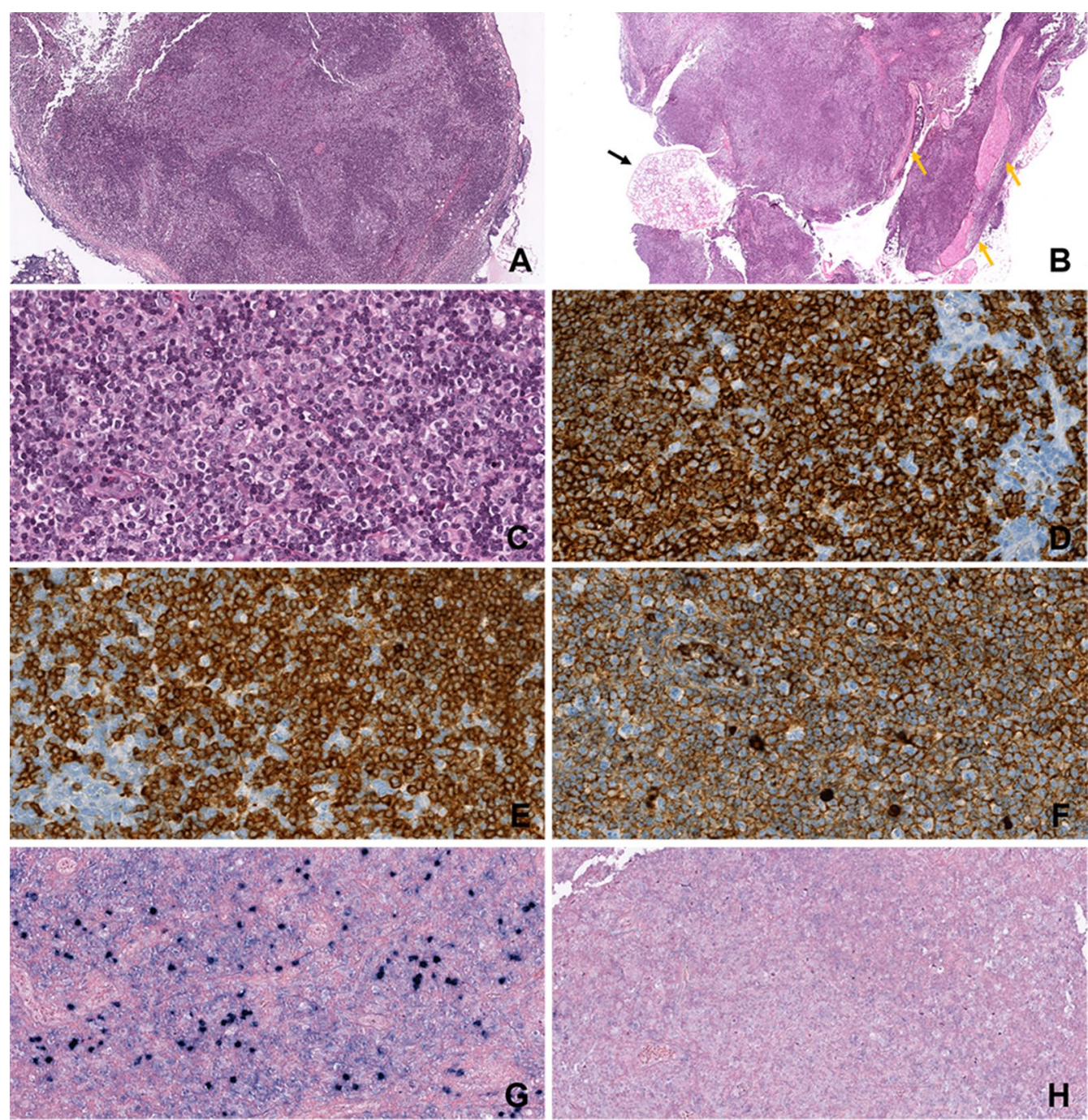

Fig. 3 A and B Light examination of tumour, low magnification (haematoxylin and eosin stain, original magnification $\times 20$ ), A Pseudo-nodular architecture of the excised lesion with some colonised lymphoid follicles with widened mantle zone in the MALT lymphoma, B Massive colonisation of the neoplastic follicles; tumour cells are scattered and infiltrate adjacent cellulo-adipose tissue with insheathing of the small nervous fillets (yellow arrow), but do not invade the healthy lobule of salivary gland (black arrow). No epithelial or salivary structure is observed in the tumour infiltrate, C Tumour cells of small size with an abundant and pale cytoplasm and irregular nuclei; these cells have rather dense chromatin nuclei with a cytoplasm sometimes off-centred and a plasma-cell differentiation (original magnification $\times 40$ ). D, E Immunohistochemical staining (original magnification $\times 40$ ), D Strong positive for CD20, E Strong positive for CD79a. F Uniform strong staining of membrane cells for lgM (original magnification $\times 20$ ). $\mathbf{G}, \mathbf{H}$ In situ hybridisation for light chain of immunoglobulin (original magnification $\times 40$ ) $\mathbf{G}$ High expression of kappa light chain $\mathbf{H}$ Absence of the expression of lambda light chain

in Table 1. This subtype of B-cell lymphoma has a better prognosis than its nodal counterparts, with a rather indolent evolution and a tendency to remain localised, as approximately only a quarter of the cases tend to disseminate to multiple sites. The most common site of development is the stomach, and the majority of gastric MALT lymphomas are associated with Helicobacter pylori infection [25]. Salivary and thyroid MALT lymphomas are associated with autoimmune disorders, such as Sjögren syndrome and Hashimoto disease, respectively [26]. Their occurrence on the mucosa of the oral cavity as primary tumours is extremely rare [24, 27], and they present mainly as mass swellings on the tongue or as nodular forms in the lip or buccal mucosa (Table 1). The clinical manifestation may lead to the histological diagnosis on a biopsy sample or a resected specimen. In our reported case, the patient did not present any clinical manifestations or symptomatology. The nodule under the mucosal 


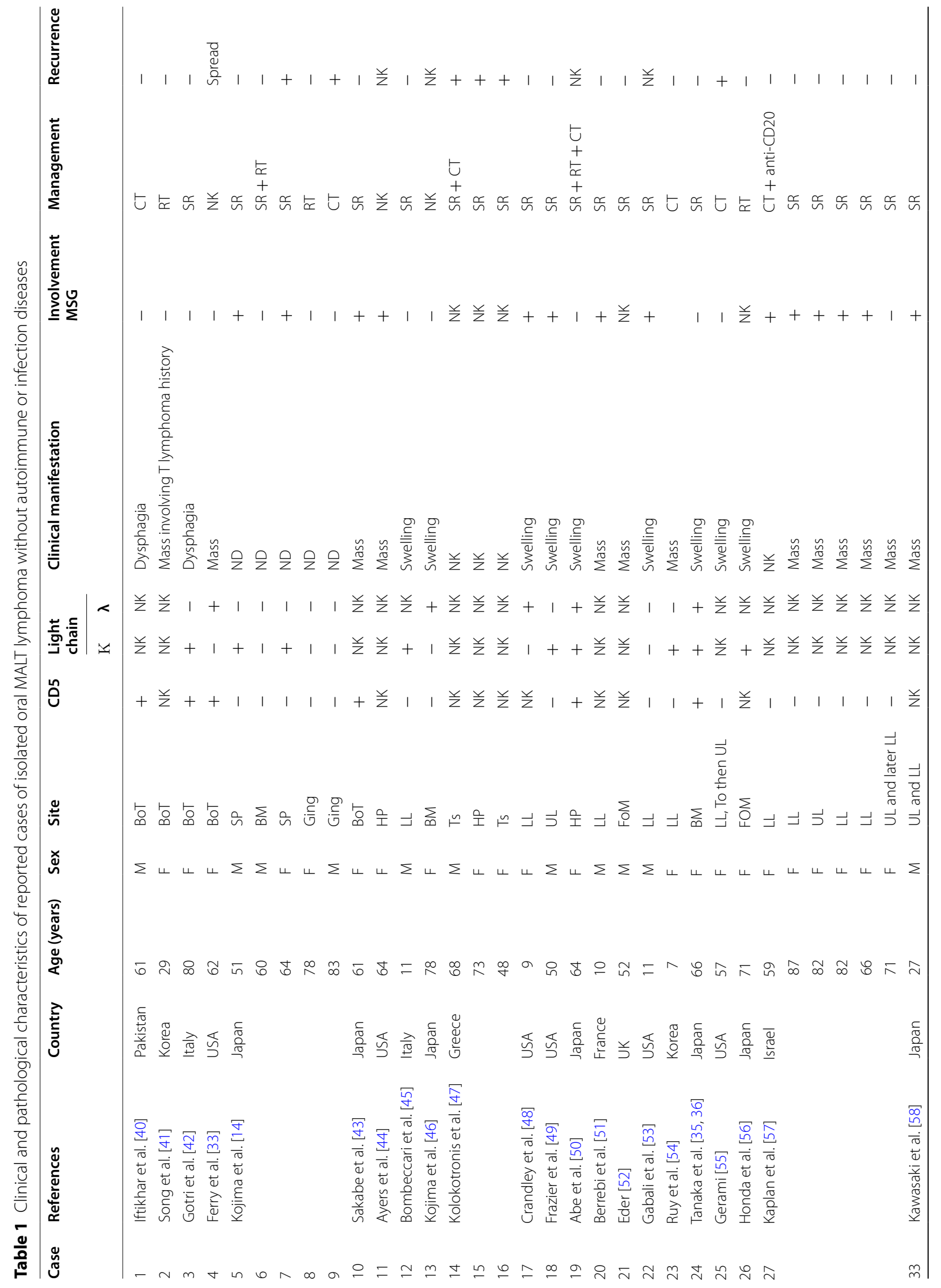




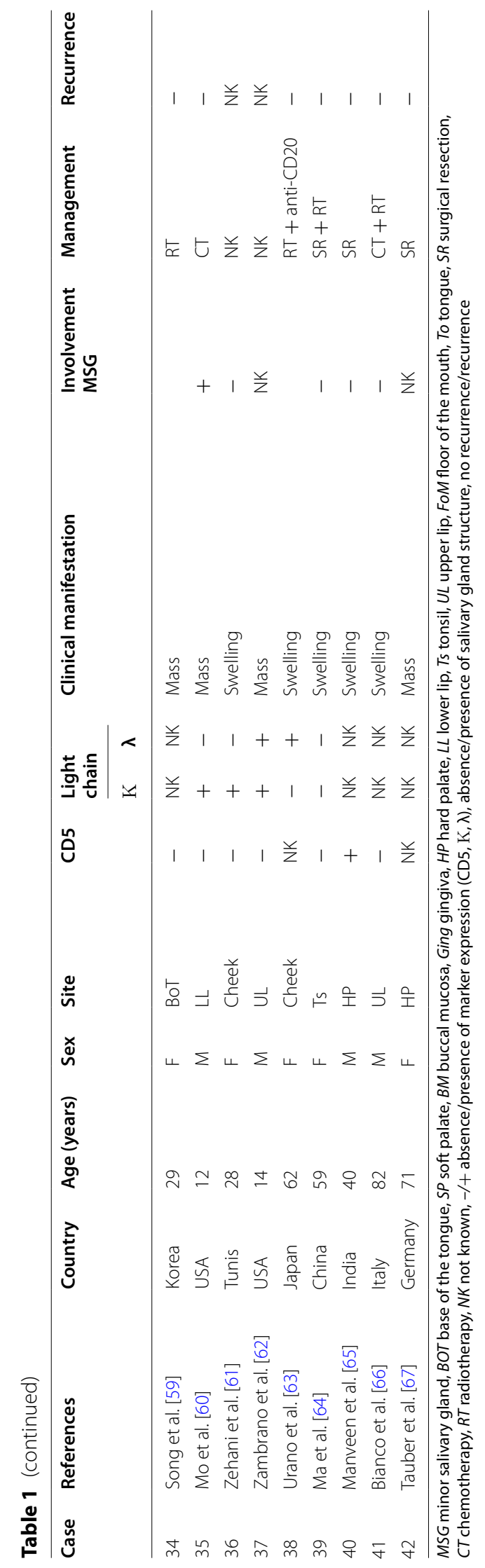


lesion was discovered fortuitously during a careful clinical examination of a 73-year-old woman with a history of IgM kappa MGUS for more than 13years with no known or identified lesions and no specific clinical manifestation. No superficial adenomegaly or splenomegaly was highlighted on physical examination, but electrophoresis of plasma proteins showed an IgM level of $5.4 \mathrm{~g} / \mathrm{L}$ at the time of MGUS discovery, which increased gradually to $13.16 \mathrm{~g} / \mathrm{L}$ at the time of detection of the right cheek mucosal nodule. The LDH level was normal, and beta- 2 microglobulin level was $2.45 \mathrm{mg} / \mathrm{L}$. Blood tests for autoimmunity were performed (anti-Sm, anti-RNP, anti-SS-A, anti-SS-B, anti-Sc70, anti-JO-1) and found to be normal, as were thyrostimulin (TSH) and thyroxin (T4) levels. Renal and liver function tests, as well as blood cell count, were normal. No proteinuria was evidenced. Serology for $\mathrm{C}$ hepatitis (HCV) was negative, and endoscopic examination of the gastrointestinal tract showed no particularity. Overall, our patient presented no specific risk factors for the development of MALT lymphoma, more particularly, of the oral mucosa, which is a rare and atypical extra nodal localisation of this type of lymphoma.

MALT lymphomas of the oral cavity can be delineated into two distinct types: the first arises from a pathologic lymphocyte infiltrate of the minor salivary glands, and the second from lymphoid cells of the mucosa, independent of inflammatory salivary disease. Under normal circumstances, the parenchyma of the salivary glands do not contain lymphocyte infiltrate, but they can acquire it in inflammatory pathological conditions, especially in Sjögren syndrome [28], which is a systemic autoimmune pathology with a lymphoepithelial sialadenitis as a hallmark feature, but also in other chronic pathologies, such as sclerotic sialadenitis or localised inflammation $[29,30]$ In our patient, the minor salivary gland lobule observed on the examined histopathological slides appeared healthy and did not show any inflammatory infiltrate (Fig. 3b); moreover, no lymphoepithelial structure was identified on anti-AE1/AE3 immunolabelled slides of the tumour tissue. These features were in favour of a primary MALT lymphoma of the oral mucosa in an atypical localisation to the cheek mucosa.

The pathological features of MALT lymphoma of the head and neck region and therefore, in the oral cavity, are similar to those of MALT lymphoma occurring elsewhere. Its immunophenotypic profile shows that lymphoma cells express B lineage markers, such as CD20, with a variable proportion of plasmocytic differentiation expressing CD79a membrane protein in one-third of cases [31]. They usually express IgM and sometimes IgG or IgA, but not IgD. Monotypic immunoglobulin lightchain expression is essential for differential diagnosis with benign lymphoid infiltrates.
The expression of CD5 by MALT lymphomas is not frequent. Differential diagnoses of other forms of CD5expressing small-cell lymphomas, such as mantle cell lymphomas and small lymphocytic lymphomas, should be made. The absence of expression of cyclin D1 distinguishes them from mantle cell lymphomas, and the absence of CD10 expression achieves differential diagnosis from most follicular lymphomas. MALT lymphomas are typically negative for CD5, CD10, BCL6 and cyclin D1. In a study of 14 cases of MALT lymphomas, Jaso et al. showed that CD5-positive immunolabelling seems to be associated with extragastric locations with a tendency to dissemination [23], but no cases were localised in the oral cavity in their series. However, CD5-positive oral MALT lymphomas have been associated with disseminated forms [32,33], and several cases of MALT lymphomas of the oral mucosa expressing both kappa and lambda light chains have been correlated with aggressive behaviour and recurrence $[8,34,35]$. Tanaka et al. reported a case of a primary MALT lymphoma of the oral mucosa that was CD5-positive and expressed kappa light chain at the time of the diagnosis, and then expressed both light-chain lambda and kappa in the recurrent lesion [35-37].

The association between the phenotypic expression profile of CD5 and the lambda and kappa light chains in MALT with either an aggressive or recurrent character remains unclear, and the CD5 phenotype can be expressed in indolent form [35], as in our patient who had a monoclonal gammopathy for more than 13 years without any lesions or suspicious radiological images. Given the age and evolution of our patient's MALT lymphoma, it can be considered indolent, although at the time of diagnosis the tumour cells were CD5-positive, in addition to kappa light chain expression. The absence of local recurrence or dissemination over 4 years of followup and, more specifically, the marked reduction of the kappa light chain monoclonal peak by electrophoresis of plasma proteins 4 years after surgical excision, reinforces the hypothesis of a primary and indolent MALT lymphoma of the oral mucosa.

Active treatment options for the management of MALT lymphoma include surgery, radiotherapy, chemotherapy, immunotherapy and combined modalities. The optimal choice is based on the disease stage and primary anatomical site. The treatment sequence for primary MALT lymphoma is assimilated to the management of an extranodal marginal zone lymphoma, with, from our observation, a specificity for oral mucosa location and a late diagnosis of the tumour in a patient with no chronic infection or dysimmunity and with a long history of MGUS. In addition, the pathological diagnosis is made based on surgical biopsy with complete excision. The tumour can be considered an isolated, single site of primary extranodal, 
non-gastric MALT lymphoma and can be stratified at the stage I of Lugano staging system or with a more modern system, such as the T1m N0 M0 of Paris staging system [38] for gastrointestinal tract lymphoma. In the absence of a target infectious agent, a practical guideline [39] must take into account the site of involvement and the potential for organ dysfunction, whether it is localised or disseminated, the morbidity associated with any proposed treatment, and the general physical condition of the person. In our case, a single-site MALT lymphoma was localised at the oral mucosa of the cheek, which is a site that does not contain an organ with a potential risk of dysfunction. The patient was in very good physical condition, with a World Health Organization (WHO) index of 0 . Under these conditions, a 'watch and wait' approach was considered, and observation without therapy was established by a multidisciplinary consultation meeting of haematology. Four years after surgical excision and lymphoma diagnosis, no local recurrence or spreading evolution were observed. This is in agreement with the observations of primary MALTs of the oral cavity reported in the literature (Table 1), in which 21 of the 42 cases $(50 \%)$ were treated by surgical excision alone, with a predominant localisation at the lips (10/21), and 17 of the 21 cases $(81 \%)$ showed no progression or recurrence during the follow-up period. Of note, all reported cases had a clinical manifestation as a first sign; in particular, swelling or a small mass. This partly explains surgical management with total excision for histopathological diagnosis. In our case, the small submucosal nodule was discovered during a thorough physical examination of the oral cavity in the context of MGUS followed for 13 years, which motivated surgical excision. The other cases reported in the literature (17/42) were treated by different associations of therapeutic modalities, combining surgery, radiotherapy, chemotherapy and anti-CD20 immunotherapy with variable results and poor and unhelpful information, given the very low number of cases.

\section{Conclusions}

This reported case is, to our knowledge, the first diagnosis of a primary oral mucosa MALT lymphoma in a patient with a monoclonal gammopathy followed for a significant amount of time. It reminds all professionals of oral medicine and surgery of the importance of meticulous and systematic physical examination of the oral mucosa, which can be the site of expression of a systemic disease and, notably, of malignant haemopathy, with a weak clinical manifestation and non-specific, especially in indolent forms. This can modify the prognosis of progression of the monoclonal gammopathy, which represents a precancerous state with a risk of developing MM or lymphoproliferative haemopathy.

\begin{abstract}
Abbreviations
MALT: Mucosa-associated lymphoid tissue; MGUS: Monoclonal gammopathy of undetermined significance; PCs: Plasma cells; MGRS: Monoclonal Gammopathy of renal significance; MM: Multiple myeloma; CT: Computer tomography; PET/CT: Positron emission tomography/computer tomography; MRI: Magnetic resonance imaging; NHL: Non-Hodgkin's lymphoma; IMWG: International Myeloma Work Group; DLBCL: Diffuse large B-cell lymphoma; TSH: Thyroid-stimulating hormone; T4: Thyroxin; HCV: C-Viral hepatitis; WHO: World Health Organization; H\&E: Hematoxylin and eosin.
\end{abstract}

\section{Acknowledgements}

We thank Doctor Martine Patey (MP) of the Department of Pathology for histopathology and diagnoses and for providing photomicrographs of the same, and for hes contribution to the writing of the pathology sections of the manuscript, Doctor Anne Quinquenel (AQ) for hes contribution to the haematological sections and proofreading of the manuscript, and Doctor Hubert Schvartz (HS) for proofreading of the pathological sections.

\section{Authors' contributions}

$\mathrm{HH}$ conceived the idea, contributed to the writing and proofreading, approved the manuscript and was involved in patient management. MP, AQ and HS contributed to the writing and proofreading of the manuscript. All authors have read and approved the manuscript.

\section{Funding}

No funding.

Availability of data and materials

Not applicable.

\section{Declarations}

Ethics approval and consent to participate

Not applicable.

\section{Consent for publication}

Written consent for publication was obtained from the patient before publication.

\section{Competing interests}

The authors declare that they have no competing interests.

\section{Author details}

'Département Médecine et Chirurgie Orales, Faculté d'Odontologie, Université de Reims Champagne Ardenne, 2, Rue du Général Koenig, 51100 Reims, France. ${ }^{2}$ Service de Chirurgie Orale, Centre Hospitalier Universitaire de Reims, Hôpital Maison Blanche, 45, Rue Cognac Jay, 51100 Reims, France. ${ }^{3}$ Laboratoire de Recherche en Nanosciences (LRN), EA 4682, Université de Reims Champagne Ardenne, Reims, France. ${ }^{4}$ Service de Pathologie, Hôpital Robert Debré, CHU de Reims, Reims, France. ${ }^{5}$ Expert Centre of Anatomopathological Network LYMPHOPATH, CHU de Reims - Hôpital Robert Debré, Reims, France.

${ }^{6}$ Service d'Hématologie Clinique, Hôpital Robert Debré, CHU de Reims, Reims, France. ${ }^{7}$ Réunion de Concertation Pluridisciplinaire Hématologie, Hôpital Robert Debré, CHU de Reims, Reims, France. ${ }^{8}$ Département de Médecine et Chirurgie Orales, Pôle de Médecine Bucco-Dentaire, Centre Hospitalier Universitaire de Reims, 45, Rue Cognacq-Jay, 51100 Reims, France.

Received: 18 August 2021 Accepted: 10 November 2021

Published online: 23 November 2021

\section{References}

1. Rajkumar SV, Dimopoulos MA, Palumbo A, Blade J, Merlini G, Mateos $\mathrm{M}-\mathrm{V}$, et al. International Myeloma Working Group updated criteria for the diagnosis of multiple myeloma. Lancet Oncol. 2014;15:e538-48.

2. Ong F, Hermans J, Noordijk EM, Wijermans PW, Seelen PJ, de Kieviet $W$, et al. A population-based registry on paraproteinaemia in The 
Netherlands. Comprehensive Cancer Centre West, Leiden, The Netherlands. Br J Haematol. 1997;99:914-20.

3. Kyle RA, Therneau TM, Rajkumar SV, Larson DR, Plevak MF, Offord JR, et al. Prevalence of monoclonal gammopathy of undetermined significance. $N$ Engl J Med. 2006;354:1362-9.

4. Leung N, Bridoux F, Hutchison CA, Nasr SH, Cockwell P, Fermand J-P, et al. Monoclonal gammopathy of renal significance: when MGUS is no longer undetermined or insignificant. Blood. 2012;120:4292-5.

5. Kyle RA, Therneau TM, Rajkumar SV, Larson DR, Plevak MF, Melton LJ. Long-term follow-up of 241 patients with monoclonal gammopathy of undetermined significance: the original Mayo Clinic series 25 years later. Mayo Clin Proc. 2004;79:859-66.

6. Kyle RA, Therneau TM, Rajkumar SV, Offord JR, Larson DR, Plevak MF, et al. A long-term study of prognosis in monoclonal gammopathy of undetermined significance. N Engl J Med. 2002;346:564-9.

7. Wöhrer S, Streubel B, Bartsch R, Chott A, Raderer M. Monoclonal immunoglobulin production is a frequent event in patients with mucosa-associated lymphoid tissue lymphoma. Clin Cancer Res Off J Am Assoc Cancer Res. 2004;10:7179-81.

8. Edinger JT, Lorenzo CR, Breneman DL, Swerdlow SH. Primary cutaneous marginal zone lymphoma with subclinical cutaneous involvement and biclonality. J Cutan Pathol. 2011;38:724-30.

9. IARC Publications Website - WHO Classification of Tumours of Haematopoietic and Lymphoid Tissues. http://publications.iarc.fr/Book-AndReport-Series/Who-larc-Classification-Of-Tumours/Who-Classification-OfTumours-Of-Haematopoietic-And-Lymphoid-Tissues-2008. Accessed 12 Jun 2017

10. Takano S, Matsushita N, Oishi M, Okamoto S, Teranishi Y, Yokota C, et al. Site-specific analysis of B-cell non-Hodgkin's lymphomas of the head and neck: a retrospective 10-year observation. Acta Otolaryngol (Stockh). 2015;135:1168-71. https://doi.org/10.3109/00016489.2015.1061700.

11. Oh SY, Ryoo B-Y, Kim WS, Park YH, Kim K, Kim HJ, et al. Nongastric marginal zone B-cell lymphoma: analysis of 247 cases. Am J Hematol. 2007;82:446-52

12. Dong $S$, Chen $L$, Chen $Y$, Chen X. Primary hepatic extranodal marginal zone B-cell lymphoma of mucosa-associated lymphoid tissue type: a case report and literature review. Medicine (Baltimore). 2017;96:e6305.

13. Matutes $E$, Montalban C. Clinical features and management of nongastrointestinal non-ocular extranodal mucosa associated lymphoid tissue (ENMALT) marginal zone lymphomas. Best Pract Res Clin Haematol. 2017;30:99-108.

14. Kojima M, Nakamura N, Shimizu K, Nishikawa M, Matsumoto M, Higuchi $\mathrm{K}$, et al. Histopathological variation of primary mucosa-associated lymphoid tissue lymphoma of the oral cavity. Pathol Oncol Res POR. 2007;13:345-9.

15. Landgren O, Kyle RA, Pfeiffer RM, Katzmann JA, Caporaso NE, Hayes RB, et al. Monoclonal gammopathy of undetermined significance (MGUS) consistently precedes multiple myeloma: a prospective study. Blood. 2009;113:5412-7.

16. Rajkumar SV. Updated diagnostic criteria and staging system for multiple myeloma. Am Soc Clin Oncol Educ Book. 2016;36:e418-23.

17. Dispenzieri A, Katzmann JA, Kyle RA, Larson DR, Melton LJ, Colby CL, et al. Prevalence and risk of progression of light-chain monoclonal gammopathy of undetermined significance: a retrospective population-based cohort study. Lancet Lond Engl. 2010;375:1721-8.

18. Fouquet G, Amouzou K, Renaud L, Carpentier B, Simonnet A, Van de Wyngaert $Z$, et al. Monoclonal gammopathies of undetermined significance do not systematically require a specialized consultation. Rev Med Interne. 2015;36:444-9.

19. Agarwal A, Ghobrial IM. Monoclonal gammopathy of undetermined significance and smoldering multiple myeloma: a review of the current understanding of epidemiology, biology, risk stratification, and management of myeloma precursor disease. Clin Cancer Res Off J Am Assoc Cancer Res. 2013:19:985-94.

20. Weiss BM, Kuehl WM. Advances in understanding monoclonal gammopathy of undetermined significance as a precursor of multiple myeloma. Expert Rev Hematol. 2010;3:165-74.

21. Rajkumar SV, Kyle RA, Therneau TM, Melton $\sqcup$, Bradwell AR, Clark RJ, et al. Serum free light chain ratio is an independent risk factor for progression in monoclonal gammopathy of undetermined significance. Blood. 2005:106:812-7.
22. Kyle RA, Durie BGM, Rajkumar SV, Landgren O, Blade J, Merlini G, et al. Monoclonal gammopathy of undetermined significance (MGUS) and smoldering (asymptomatic) multiple myeloma: IMWG consensus perspectives risk factors for progression and guidelines for monitoring and management. Leukemia. 2010;24:1121-7.

23. Silva TDB, Ferreira CBT, Leite GB, de Menezes Pontes JR, Antunes HS. Oral manifestations of lymphoma: a systematic review. Ecancermedicalscience. 2016;10:665.

24. Takahashi H, Fujita S, Okabe H, Tsuda N, Tezuka F. Immunophenotypic analysis of extranodal non-Hodgkin's lymphomas in the oral cavity. Pathol Res Pract. 1993;189:300-11.

25. Diaconu S, Predescu A, Moldoveanu A, Pop C, Fierbințeanu-Braticevici C. Helicobacter pylori infection: old and new. J Med Life. 2017;10:112-7. http://www.ncbi.nlm.nih.gov/pmc/articles/PMC5467250/. Accessed 27 Jun 2017.

26. Guitart J, Deonizio J, Bloom T, Martinez-Escala ME, Kuzel TM, Gerami P, et al. High incidence of gastrointestinal tract disorders and autoimmunity in primary cutaneous marginal zone B-cell lymphomas. JAMA Dermatol. 2014;150:412-8. https://doi.org/10.1001/jamadermatol.2013.9223.

27. Solomides CC, Miller AS, Christman RA, Talwar J, Simpkins H. Lymphomas of the oral cavity: Histology, immunologic type, and incidence of Epstein-Barr virus infection. Hum Pathol. 2002;33:153-7. https://doi.org/ 10.1053/hupa.2002.30721.

28. Titsinides S, Nikitakis N, Piperi E, Sklavounou A. MALT lymphoma of minor salivary glands in a Sjögren's syndrome patient: a case report and review of literature. J Oral Maxillofac Res. 2017;8:e5.

29. Harris NL. Lymphoid proliferations of the salivary glands. Am J Clin Pathol. 1999;111(1 Suppl 1):S94-103.

30. Wöhrer S, Troch M, Streubel B, Zwerina J, Skrabs C, Formanek M, et al. MALT lymphoma in patients with autoimmune diseases: a comparative analysis of characteristics and clinical course. Leukemia. 2007;21:1812-8.

31. Oh SY, Ryoo B-Y, Kim WS, Park YH, Kim K, Kim HJ, et al. Nongastric marginal zone B-cell lymphoma: analysis of 247 cases. Am J Hematol. 2007;82:446-52.

32. Wenzel C, Dieckmann K, Fiebiger W, Mannhalter C, Chott A, Raderer M. CD5 expression in a lymphoma of the mucosa-associated lymphoid tissue (MALT)-type as a marker for early dissemination and aggressive clinical behaviour. Leuk Lymphoma. 2001;42:823-9.

33. Ferry JA, Yang WI, Zukerberg LR, Wotherspoon AC, Arnold A, Harris NL. CD5+ extranodal marginal zone B-cell (MALT) lymphoma. A low grade neoplasm with a propensity for bone marrow involvement and relapse. Am J Clin Pathol. 1996;105:31-7.

34. Fujiwara T, Ishizawa K, Kohata K, Yamamoto J, Yamada MF, Kameoka J, et al. Aggressive B-cell lymphoma with dual surface immunoglobulin light-chain expression. Intern Med Tokyo Jpn. 2007;46:1458-61.

35. Tanaka T, Kitabatake K, lino M, Goto K. Immunohistochemical comparison of $\mathrm{CD}$, lambda, and kappa expression in primary and recurrent buccal mucosa-associated lymphoid tissue (MALT) lymphomas. Diagn Pathol. 2011;6:82.

36. Tanaka T, lino M.t (11;18)(q21;q21) chromosome translocation (A1446-M1150) of MALT lymphoma in buccal mucosa. J Cancer Res Clin Oncol. 2010;136:1783-5.

37. Tanaka T, Kitabatake K, lino M, Goto K. Tetraploidy with double t(11;18) of recurrent MALT lymphoma in buccal mucosa: a case report. Oral Surg Oral Med Oral Pathol Oral Radiol. 2012;113:399-403.

38. Zucca E, Arcaini L, Buske C, Johnson PW, Ponzoni M, Raderer M, et al. Marginal zone lymphomas: ESMO clinical practice guidelines for diagnosis, treatment and follow-up. Ann Oncol Off J Eur Soc Med Oncol. 2020;31:17-29.

39. Non-Hodgkin's lymphoma overview-NICE Pathways. https://pathways. nice.org.uk/pathways/non-hodgkins-lymphoma. Accessed 16 Jun 2020.

40. Iftikhar H, Siddiqui MI, Minhas K. MALT lymphoma of the base of the tongue: a rare case entity. BMJ Case Rep. 2016. https://doi.org/10.1136/ bcr-2015-213830.

41. Song JH, Sun DI, Hong YS, Park GS, Kim YS. MALT lymphoma at the base of tongue of a 29-year-old woman treated with radiation therapy alone. J Cancer Res Ther. 2014;10:407-9.

42. Goteri G, Ascani G, Filosa A, Rubini C, Olay S, Balercia P. Primary malt lymphoma of the tongue. Med Oral Patol Oral Cirugia Bucal. 2004;9:461-3.

43. Sakabe H, Bamba M, Nomura K, Kitamura S, Segawa H, Yasui H, et al. MALT lymphoma at the base of the tongue developing without any 
background of immunodeficiency or autoimmune disease. Leuk Lymphoma. 2003;44:875-8.

44. Ayers LS, Oxenberg J, Zwillenberg S, Ghaderi M. Marginal-zone B-cell lymphoma of the bony palate presenting as sinusitis. Ear Nose Throat J. 2008:87:36-8

45. Bombeccari GP, Guzzi G, Ruffoni D, Gianatti A, Mariani U, Spadari F. Mucosa-associated lymphatic tissue lymphoma of the lower lip in a child. J Pediatr Surg. 201 1;46:2414-6.

46. Kojima M, Hirabayashi K, Yokoyama J, Uesawa M, Tsunoda S, Igarashi S Marginal zone B-cell lymphoma arising from buccal mucosa resembling inflammatory myofibroblastic tumor of the soft tissue. Head Neck Pathol. 2008:2:218-21.

47. Kolokotronis A, Konstantinou N, Christakis I, Papadimitriou P, Matiakis A, Zaraboukas T, et al. Localized B-cell non-Hodgkin's lymphoma of oral cavity and maxillofacial region: a clinical study. Oral Surg Oral Med Oral Pathol Oral Radiol Endod. 2005;99:303-10.

48. Crandley KNB, Aguiar MA, Lowe EJ. MALT lymphoma of the lip. Pediatr Blood Cancer. 2011;56:683-4.

49. Frazier JJ, Flint DJ. Primary mucosa-associated lymphoid tissue (MALT) lymphoma of the minor salivary glands in the upper and lower lips of a male paediatric patient. J Oral Med Toxicol. 2017;1:14-6. http://www.allie dacademies.org/abstract/primary-mucosaassociated-lymphoid-tissuemalt-lymphoma-of-the-minorrnsalivary-glands-in-the-upper-and-lowerlips-of-a-male-paediat-6871.html. Accessed 13 Jun 2017.

50. Abe S, Yokomizo N, Kobayashi Y, Yamamoto K. Confirmation of immunoglobulin heavy chain rearrangement by polymerase chain reaction using surgically obtained, paraffin-embedded samples to diagnose primary palate mucosa-associated lymphoid tissue lymphoma: a case study. Int J Surg Case Rep. 2015;10:129-33.

51. Berrebi D, Lescoeur B, Faye A, Faure C, Vilmer E, Peuchmaur M. MALT lymphoma of labial minor salivary gland in an immunocompetent child with a gastric Helicobacter pylori infection. J Pediatr. 1998;133:290-2.

52. Eder A. Sub-mucosal swelling. Br Dent J. 2018;224:286-7. https://doi.org/ 10.1038/sj.bdj.2018.177.

53. Gabali A, Ross CW, Edwards PC, Schnitzer B, Danciu TE. Pediatric extranodal marginal zone B-cell lymphoma presenting as amyloidosis in minor salivary glands: a case report and review of the literature. J Pediatr Hematol Oncol. 2013;35:e130-3.

54. Ryu M, Han S, Che Z, Min Y, Yoo KH, Koo HH, et al. Pediatric mucosaassociated lymphoid tissue (MALT) lymphoma of lip: a case report and literature review. Oral Surg Oral Med Oral Pathol Oral Radiol Endod. 2009:107:393-7.

55. Gerami P. Oral mucosal MALT lymphoma clinically simulating oral facial granulomatosis. Int J Dermatol. 2007:46:868-71.
56. Honda K, Kusama H, Takagi S, Sekine S, Noguchi M, Chiba H. Diagnosis of intra-oral MALT lymphoma using seminested polymerase chain reaction. Br J Oral Maxillofac Surg. 2004;42:28-32.

57. Kaplan I, Shuster A, Frenkel G, Avishai G, Allon I, Raiser V. Non-Hodgkin lymphoma of the lips: a rare entity. Acta Histochem. 2019;121:151449.

58. Kawasaki G, Yanamoto S, Kawano T, Yoshitomi I, Yamada S-I, Rokutanda S, et al. Soft masses occurring simultaneously in the upper and lower lips. Oral Surg Oral Med Oral Pathol Oral Radiol. 2014;117:147-52.

59. Song JH, Sun DI, Hong YS, Park GS, Kim YS. MALT lymphoma at the base of tongue of a 29-year-old woman treated with radiation therapy alone. J Cancer Res Ther. 2014;10:407-9.

60. Mo JQ, Dimashkieh H, Mallery SR, Swerdlow SH, Bove KE. MALT lymphoma in children: case report and review of the literature. Pediatr Dev Pathol Off J Soc Pediatr Pathol Paediatr Pathol Soc. 2004;7:407-13.

61. Zehani A, Chelly I, Chahed H, Besbes G, Haouet S, Kchir N. A confusing swelling of the buccal mucosa. Ann Pathol. 2016:36:139-42.

62. Zambrano E, Mejía-Mejía O, Bifulco C, Shin J, Reyes-Múgica M. Extranodal marginal zone B-cell lymphoma/maltoma of the lip in a child: case report and review of cutaneous lymphoid proliferations in childhood. Int I Surg Pathol. 2006:14:163-9.

63. Urano M, Kiriyama Y, Abe M, Kuroda M, Mizoguchi Y, Sakurai K. A case of mucosa-associated lymphoid tissue (MALT) lymphoma arising in the accessory parotid gland. Oral Med Pathol. 2007;12:19-22.

64. Ma S, Jug R, Shen S, Zhang W-L, Xu H-T, Yang L-H. Marginal zone lymphoma of palatine tonsil with prominent plasmacytic differentiation: a CARE-compliant article and review of literature. Medicine (Baltimore). 2018;97:e9648

65. Manveen JK, Subramanyam R, Harshaminder G, Madhu S, Narula R. Primary B-cell MALT lymphoma of the palate: a case report and distinction from benign lymphoid hyperplasia (pseudolymphoma). J Oral Maxillofac Pathol JOMFP. 2012;16:97-102.

66. Bianco L, Solla SD, Parvis G, Gino E, Bollito E, Filippi AR, et al. Lowdose radiotherapy for extranodal marginal zone $B$ lymphoma of the lip: case report and literature review. Hematol Oncol Stem Cell Ther. 2021;14(1):76-81.

67. Tauber S, Nerlich A, Lang S. MALT lymphoma of the paranasal sinuses and the hard palate: report of two cases and review of the literature. Eur Arch Oto Rhino Laryngol Off J Eur Fed Oto Rhino Laryngol Soc EUFOS Affil Ger Soc Oto Rhino Laryngol Head Neck Surg. 2006;263:19-22.

\section{Publisher's Note}

Springer Nature remains neutral with regard to jurisdictional claims in published maps and institutional affiliations.
Ready to submit your research? Choose BMC and benefit from:

- fast, convenient online submission

- thorough peer review by experienced researchers in your field

- rapid publication on acceptance

- support for research data, including large and complex data types

- gold Open Access which fosters wider collaboration and increased citations

- maximum visibility for your research: over 100M website views per year

At BMC, research is always in progress.

Learn more biomedcentral.com/submissions 